\title{
Peroxisome proliferator-activated receptor- $\gamma$ suppresses CYP11B2 expression and aldosterone production
}

\author{
Akira Uruno ${ }^{1}$, Ken Matsuda ${ }^{2}$, Naoya Noguchi ${ }^{1}$, Takeo Yoshikawa ${ }^{1}$, Masataka Kudo ${ }^{2}$, \\ Fumitoshi Satoh ${ }^{2}$, William E Rainey ${ }^{4}$, Xiao-Gang Hui ${ }^{3}$, Jun-ichi Akahira ${ }^{3}$, \\ Yasuhiro Nakamura ${ }^{3}$, Hironobu Sasano ${ }^{3}$, Hiroshi Okamoto', Sadayoshi Ito ${ }^{2}$ \\ and Akira Sugawara ${ }^{1}$ \\ ${ }^{1}$ Department of Advanced Biological Sciences for Regeneration, ${ }^{2}$ Division of Nephrology, Endocrinology and Vascular Medicine and ${ }^{3}$ Department of Pathology, \\ Tohoku University Graduate School of Medicine, 2-1, Seiryo-machi, Aoba-ku, Sendai 980-8575, Japan \\ ${ }^{4}$ Department of Physiology, Medical College of Georgia, Augusta, Georgia 30912, USA \\ (Correspondence should be addressed to A Sugawara; Email: akiras2i@med.tohoku.ac.jp)
}

\begin{abstract}
Peroxisome proliferator-activated receptor- $\gamma$ (PPAR $\gamma$ ) is a nuclear receptor for the antidiabetic agent thiazolidinedione, which exerts various physiological activities, independent of lowering blood glucose. However, the role of PPAR $\gamma$ in aldosterone production has not been clarified. The objective of this study was to investigate the effect of PPAR $\gamma$ on aldosterone synthase gene (CYP11B2) expression and aldosterone production. Localization of PPAR expression in normal adrenal cortex was determined by immunohistochemistry. Aldosterone production and CYP11B2 expression levels were determined using human adrenocortical carcinoma H295R cells. Pioglitazone suppressed angiotensin II-induced aldosterone secretion and CYP11B2 expression. PPAR $\gamma$ was expressed in zona glomerulosa in human normal adrenal gland. PPAR $\gamma$ overexpression enhanced pioglitazone-mediated CYP11B2 transrepression. The pioglitazone-mediated suppression of aldosterone secretion and CYP11B2 expression were canceled by PPAR $\gamma$ L466A/E469A mutant. Pioglitazone also suppressed potassium-mediated CYP11B2 induction, but not N6-2'-Odibutyladenosine-3',5'-cyclic monophosphate stimulation. Rosiglitazone and GW1929 also suppressed CYP11B2 transactivation. Mutation analysis revealed that the Ad1/CRE element in CYP11B2 $5^{\prime}$-flanking region was responsible for the pioglitazone-mediated transrepression. Pioglitazone suppressed ionomycin and a truncated constitutively active form $\mathrm{Ca}^{2+}$ /calmodulin-dependent kinase I (CaMKI)-mediated CYP11B2 transcriptional activation. A CaMK inhibitor KN-93 attenuated pioglitazone-mediated CYP11B2 transrepression. PPAR $\gamma$ suppresses $C Y P 11 B 2$ expression and aldosterone secretion.
\end{abstract}

Journal of Molecular Endocrinology (2011) 46, 37-49

\section{Introduction}

Nuclear receptor peroxisome proliferator-activated receptor- $\gamma(\operatorname{PPAR} \gamma)$, which is targeted by the antidiabetic agent thiazolidinedione (TZD), is abundantly expressed in adipose tissue and acts as a key regulator for adipocyte differentiation. PPAR $\gamma$ also is expressed in various tissues involved in metabolic functions including skeletal muscle, liver, and pancreas (Heikkinen et al. 2007).

Additionally, roles of PPAR $\gamma$ in cardiovascular disorders including atherosclerosis/hypertension have been reported. PPAR $\gamma$ agonists prevent macrovascular events in type 2 diabetic patients, independent of glycemic control (Dormandy et al. 2005). PPAR $\gamma$ agonists also prevent hypertension in high-fat-fed Zuker rats (Walker et al. 1999) and renin/angiotensinogen double-transgenic mice (Ryan et al. 2004). Moreover, the human PPAR $\gamma$ dominant negative mutant induces hypertension and metabolic dysfunctions (Barroso et al. 1999), and vascular smooth muscle cell (VSMC)-specific PPAR $\gamma$ dominant negative mutant transgenic mice develop impaired vasodilation and hypertension (Sugawara et al. 2001). We have previously shown that PPAR $\gamma$ agonists suppress angiotensin II (AII) type 1 receptor (Halabi et al. 2008) and thromboxane receptor (Sugawara et al. 2002) in VSMCs as well as macrophage activation (Jiang et al. 1998, Ricote et al. 1998) and thromboxane synthase expression in macrophages (Ikeda et al. 2000). Thus, VSMCs and macrophages are important targets of PPAR $\gamma$ against atherosclerosis/hypertension. Additionally, some PPAR $\gamma$ agonist is reported to decrease AII-induced plasma aldosterone levels in Sprague-Dawley rats (Diep et al. 2002).

Aldosterone is an important factor in the progression of hypertension and vascular damage. Although adrenalectomy ameliorates vascular injury 
in AII/salt-treated rats, independent of systemic blood pressure, administration of aldosterone abolishes the adrenalectomy effects (Rocha et al. 2000, 2002). PPAR $\gamma$ is shown to affect several aldosterone regulatory factors including an increase in renin expression (Todorov et al. 2007) and body fluid volume by sodium absorption from the collecting ducts in the kidney (Guan et al. 2005), and a decrease in AII secretion from adipocytes (Harte et al. 2005). Despite the fact that some PPAR $\gamma$ agonists decrease plasma aldosterone levels in rats (Diep et al. 2002), direct effects of PPAR $\gamma$ on aldosterone secretion in the adrenal gland are unknown.

Steroid hormone biosynthesis is rapidly regulated by the translocation of substrate cholesterol from the outer mitochondrial membrane to the inside of mitochondria (Rainey et al. 2004). In contrast, chronic aldosterone secretion is limited by the expression of the aldosterone synthase gene, CYP11B2. In this study, we have investigated the roles of PPAR $\gamma$ on CYP11B2 expression/aldosterone secretion using adrenocortical H295R cells.

\section{Materials and methods}

\section{Reagents}

Pioglitazone, rosiglitazone, GW1929, and GW9662 were purchased from Alexis Biochemicals (Farmingdale, NY, USA). Human AII and N6-2'-O-dibutyladenosine-3', $5^{\prime}$-cyclic monophosphate (dbcAMP) were purchased from Sigma. KN-93 was purchased from Calbiochem (La Jolla, CA, USA). HX630 was kindly provided by Dr Kagechika (Tokyo Medical and Dental University).

\section{Plasmids}

The subcloned chimeric constructs containing the human CYP11B2 genomic DNA and luciferase cDNA (pGL3-basic, Promega) were used for the transient transfection studies: - 1521/+2-luc (harboring the CYP11B2 5'-flanking region from -1521 to +2 relative to the transcription start site upstream of the luciferase cDNA in pGL3-basic); -747/ + 2-luc; - 135/+2-luc; $-65 /+2$-luc. $\beta$-Galactosidase control plasmid in pCMV (pCMV- $\beta$-gal) was purchased from Clontech. Murine PPAR $\gamma 1$ expression vector (pCMX-PPAR $\gamma 1$ ) was kindly provided by Dr Umesono (Kyoto University). Truncated human $\mathrm{Ca}^{2+} /$ calmodulin-dependent kinase I (CaMKI, residues 1-295; Sun et al. 1996) and murine Nur-related factor 1 (NURR1) cDNA were cloned by PCR from normal human dermal fibroblast or murine pituitary AtT20 cell RNA and cloned into the pcDNA3 expression vector (Invitrogen; CaMKI-295-pcDNA3 and NURR1-pcDNA3). Several vectors were mutated using a QuikChange site-directed mutagenesis kit (Stratagene, La Jolla, CA, USA); activation function domain 2 (AF-2 domain) in pCMX-PPAR $\gamma 1$ from L466 to A and E469 to A (pCMX-PPAR $\gamma 1$ L466A/E469A); Ad5 element in -1521/+2-luc from 5'-CTCCAGCCTTGACCTT-3' ${ }^{\prime}$ to $5^{\prime}$-CTCCAGCCTTGAtaTc- ${ }^{\prime}$ $(-1521 /+2$-luc-Ad5-mut); Ad1/CRE element in $-1521 /+2$-luc from $5^{\prime}$-TGACGTGA-3 ${ }^{\prime}$ to $5^{\prime}$-gGtaccGA-3' (-1521/+2-luc-Ad1/CRE-mut; Bassett et al. 2004). Ad1/CRE element of CYP11B2 gene promoter (CAGTTCTCCCATGACGTGATATGTTTCC) was inserted into the upstream of pGL3-promoter vector (Promega; Ad1/CRE-SV-Luc).

\section{Cell culture}

H295R cells were grown with 1:1 mixture of DMEM and Ham's F12 medium supplemented with $10 \%$ fetal bovine serum (FBS), insulin-transferrin-selenium-G supplements (Invitrogen), $1.25 \mathrm{mg} / \mathrm{ml}$ BSA (Sigma), $5 \cdot 35 \mu \mathrm{g} / \mathrm{ml}$ linoleic acid (Sigma), $100 \mathrm{U} / \mathrm{ml}$ penicillin, and $100 \mu \mathrm{g} / \mathrm{ml}$ streptomycin. Cells were cultured in a humidified incubator at $37^{\circ} \mathrm{C}$ with $5 \% \mathrm{CO}_{2}$. SW-13 cells were provided by Health Science Research Resources Bank, and were grown in Leibovitz's L-15 supplemented with $10 \% \mathrm{FBS}, 100 \mathrm{U} / \mathrm{ml}$ penicillin, and $100 \mu \mathrm{g} / \mathrm{ml}$ streptomycin in a humidified incubator at $37^{\circ} \mathrm{C}$ with air.

\section{RNA preparation and quantitative reverse transcription-PCR}

Human total RNAs from normal heart (pooled from three male Caucasians, aged 30-39; cause of death: trauma), liver (from a 51-year-old male Caucasian; cause of death: sudden death), kidney (from a 40-yearold female Caucasian; cause of death: sudden death), skeletal muscle (pooled from two male/female Caucasians, aged 43 and 46; cause of death: sudden death), and adrenal gland (pooled from 62 male/female Caucasians, aged 15-61; cause of death: sudden death) were obtained from Clontech. When H295R cells were grown to $80 \%$ confluence in six-multiwell plates, they were exposed to pioglitazone for $48-72 \mathrm{~h}$ in DMEM supplemented with $1 \%$ stripped FBS. Then the cells were treated with AII, KCl, or dbcAMP. H295R and SW-13 cell total RNA were extracted using TaKaRa FastPure RNA kit (Takara Bio, Ohtsu, Japan) according to the manufacturer's instructions. Total RNAs were subjected to reverse transcription reaction using PrimeScript Reverse Transcriptase (Takara Bio) with random 6 mer and oligo dT primers according to the manufacturer's instructions. Thereafter, obtained templates were used for quantitative real-time PCR $\left(95{ }^{\circ} \mathrm{C}, 3 \mathrm{~min}\right.$ for $1 \mathrm{cycle} ; 95^{\circ} \mathrm{C}, 15 \mathrm{~s} ; 60{ }^{\circ} \mathrm{C}, 10 \mathrm{~s} ; 72^{\circ} \mathrm{C}$, 
$20 \mathrm{~s}$ for 40 cycles) with iQ Supermix (for CYP11B2) or iQ SYBR Green Supermix (for others; Bio-Rad) by DNA Engine thermal cycler attached to Chromo4 detector (Bio-Rad). The following primer and TaqMan probe sequences were used: PPAR $\gamma$ (forward, $5^{\prime}$-GACCTGAAACTTCAAGAGTACC-3' ${ }^{\prime}$, reverse, 5'-TGAGGCTTATTGTAGAGCTGAG-3' ${ }^{\prime}$ ), CYP11B2 (forward, 5'-GGCAGAGGCAGAGATGCTG-3' ${ }^{\prime}$, reverse, 5'-CTTGAGTTAGTGTCTCCACCAGGA-3' ${ }^{\prime}$, probe， 5'-CTGCACCACGTGCTGAAGCACT- ${ }^{\prime}$ ), $\beta$-actin (forward, $5^{\prime}$-CCAACCGCGAGAAGATGACC-3 ${ }^{\prime}$, reverse, $5^{\prime}$-CCAGAGGCGTACAGGGATAG-3 ${ }^{\prime}$ ), calmodulin (CaM) 1 (forward, $5^{\prime}$-AACAGAAGCTGAATTGCAGG-3 ${ }^{\prime}$, reverse, $5^{\prime}$-AATTCGGGGAAGTCAATGG-3' ${ }^{\prime}$ ), CaM2 (forward, $5^{\prime}$-GATGAAATGATCAGGGAAGC-3' ${ }^{\prime}$, reverse, 5'-CAAGGTCTTCACTTTGCTGTC-3'), CaM3 (forward, 5'-GATGGCCAGAAAGATGAAGG-3', reverse, 5'-TGATGTAGCCATTCCCATCC-3'), $\mathrm{Ca}^{2+}$ /CaMK I (sense, 5'-AAGGCAGCATGGAGAATGAG-3' ${ }^{\prime}$ reverse, 5'-CTACAATGTTGGGGTGCTTG-3'), and CaMKIV (forward, $5^{\prime}$-TGCTGCAGATGCCGTTAAAC-3' , reverse, 5'-AGATCACGATGGACAATCCC-3') .

\section{Immunohistochemistry}

Immunohistochemistry of normal human adrenal cortex from autopsy files of Tohoku University Hospital was performed by the streptavidin-biotin amplification method using Histofine kit (Nichirei, Tokyo, Japan). Antigen retrieval was performed by heating the slides in an autoclave at $120^{\circ} \mathrm{C}$ for $5 \mathrm{~min}$ in citric acid buffer (2 $\mathrm{mM}$ citric acid and $9 \mathrm{mM}$ trisodium citrate dehydrate $(\mathrm{pH} 6 \cdot 0))$. Rabbit polyclonal antibody raised against PPAR $\gamma$ was as previously described (Sato et al. 2004). The primary antibody was diluted at 1:3000, and the antigen-antibody complex was visualized with 3,3'-diaminobenzidine (DAB) solution ( $1 \mathrm{mM} \mathrm{DAB}$, $50 \mathrm{mM}$ Tris- $\mathrm{HCl}$ buffer $(\mathrm{pH} 7 \cdot 6)$, and $0 \cdot 006 \% \mathrm{H}_{2} \mathrm{O}_{2}$ ). As a negative control, normal mouse or rabbit IgG was used instead of the primary antibody. Some specimens were stained with hematoxylin. Peptide pre-absorption of the antibody was performed as described previously (Sato et al. 2004).

\section{Protein preparation and western immunoblot analysis}

Nuclear protein was prepared from H295R cells using Nuclear Extract kit (Active Motif, Carlsbad, CA, USA) according to the manufacturer's instructions. The denatured samples were separated on an SDS-polyacrylamide gel and transferred onto polyvinylidene fluoride (PVDF) membrane (Bio-Rad; Uruno et al. 2004, 2005, 2008). The membranes were then blocked with $5 \%$ nonfat dry milk and probed with primary antibody for PPAR $\gamma$ (Sato et al. 2004; diluted at 1:1000), and HRP-conjugated antibody (GE Healthcare,
Waukesha, WI, USA). The bands were visualized with ECL-plus reagent (GE Healthcare). Pre-absorption test was performed for PPAR $\gamma$ using the blocking peptide.

\section{Measurement of aldosterone concentration}

When H295R cells were grown to confluence in 24-multiwell plates, they were exposed to pioglitazone for 48-72 h in DMEM supplemented with $1 \%$ stripped FBS. AII was then added to the media at a concentration of $100 \mathrm{nmol} / \mathrm{l}$, and the cells were incubated for $2 \mathrm{~h}$. Next, the media were freshly changed, and the cells were further incubated in the presence of pioglitazone and AII for $2 \mathrm{~h}$. Aldosterone concentrations of the media were thereafter measured by Aldosterone EIA kit (Cayman Chemical, Ann Arbor, MI, USA) according to the manufacturer's instructions.

\section{Transient transfection and luciferase assay}

When H295R cells were grown to $80 \%$ confluence in 24-multiwell plates, they were transiently transfected with $200 \mathrm{ng}$ luciferase-reporter plasmids and $100 \mathrm{ng}$ pCMV- $\beta$-gal using Lipofectamine LTX and Plus reagent (Invitrogen) for $48 \mathrm{~h}$ according to the manufacturer's instructions. In some experiments, expression vectors including pCMX-PPAR $\gamma 1$ (100 ng, if not otherwise specified), pCMX-PPAR $\gamma 1$ L466A/E469A (100 ng), or pcDNA3-CaMKI-295 (200 ng) also were transfected. The media were changed to DMEM supplemented with $1 \% \mathrm{charcoal} /$ resin-treated (stripped) FBS, and the cells were incubated with or without PPAR $\gamma$ agonists for the indicated times. Then the cells were treated with AII $(100$ or $200 \mathrm{nmol} / \mathrm{l}), \mathrm{KCl}$ $\left(10 \cdot 4 \mathrm{mmol} / \mathrm{l}, 16 \mathrm{mEq} / 1\right.$ of $\left.\mathrm{K}^{+}\right)$, dbcAMP $(1 \mathrm{mmol} / \mathrm{l})$, or ionomycin $(1 \mu \mathrm{mol} / \mathrm{l})$. After appropriated treatments, they were washed with PBS, and the cell extracts were prepared using Glo Lysis buffer (Promega). Luciferase activity was measured using Bright-Glo reagents (Promega), and $\beta$-galactosidase activity was simultaneously measured. Data were normalized by $\beta$-galactosidase activity.

\section{Measurement of intracellular calcium}

H295R cells $\left(4 \times 10^{4}\right)$ were seeded into 96-well plates, and the cells were incubated for $24 \mathrm{~h}$. They were transiently transfected with $20 \mathrm{ng}$ pCMX-PPAR $\gamma 1$ using Lipofectamine LTX and Plus reagent (Invitrogen) for $48 \mathrm{~h}$, then were exposed to $3 \mu \mathrm{mol} / \mathrm{l}$ pioglitazone in DMEM supplemented with $1 \%$ strriped FBS for $24 \mathrm{~h}$. Thereafter, the cells were loaded with Fluo4-AM (Dojindo, Kumamoto, Japan; $5 \mu \mathrm{g} / \mathrm{ml}$ ) in the presence of $1.25 \mathrm{mmol} / \mathrm{l}$ probenecid (Dojindo) and 0.04\% Pluronic F-12 (Dojindo) for $1 \mathrm{~h}$. 
They were then washed with PBS, and the recording medium containing $1.25 \mathrm{mmol} / \mathrm{l}$ probenecid, and AII $(100 \mathrm{nmol} / \mathrm{l})$ or $\mathrm{KCl}(40 \mathrm{mmol} / \mathrm{l})$ was added to the media. The change of intracellular calcium was determined by fluorescent intensity (excitation at $485 \mathrm{~nm}$, emission at $535 \mathrm{~nm}$ ).

\section{Statistical analysis}

All data are presented as mean \pm s.E.M. Statistical analyses were performed with ANOVA followed by Fisher's least significant difference post hoc test.

\section{Results}

\section{PPAR $\gamma$ expression in normal adrenal gland and H295R cells}

We first examined PPAR $\gamma$ expression levels in the normal human adrenal gland and H295R cells. PPAR mRNA expression in the adrenal gland was lower than that in the kidney and heart, while higher than that in the liver, skeletal muscle, and H295R cells, and was rarely expressed in SW-13 adrenocortical carcinoma cells (Fig. 1A). Next, we determined the localization of PPAR $\gamma$ in the normal human adrenal cortex by immunohistochemistry. As shown in Fig. 1B (left panel), PPAR $\gamma$ was predominantly expressed in zona glomerulosa, while little in zona fasciculata and reticularis. The nuclear staining of human adrenal cortex with the PPAR $\gamma$ antibody was diminished with pre-absorption by its antigen peptide (Fig. 1B, right panel). Western blot analysis using anti-PPAR $\gamma$ antibody also revealed the expression of PPAR $\gamma$ protein in H295R cells nuclear protein, the band of which was abrogated by pre-absorption with the blocking peptide (Fig. 1C).

\section{Effects of pioglitazone on aldosterone secretion/ CYP11B2 expression}

We next examined the effect of a TZD pioglitazone on aldosterone secretion/CYP11B2 expression. AII treatment increased aldosterone secretion from H295R cells into the media, and pioglitazone co-treatment suppressed the AII-induced aldosterone secretion (Fig. 1D). To evaluate the effect of CYP11B2 genemediated regulation of aldosterone secretion, but not steroidogenic acute regulatory protein-mediated acute phase secretion, the media were changed once $2 \mathrm{~h}$ after AII stimulation. AII treatment also induced CYP11B2 mRNA as well as gene transcriptional activity in H295R cells, and pioglitazone co-treatment reduced the AII-mediated inductions (Fig. 1E and F).

\section{Effects of PPAR $\gamma$ on aldosterone secretion/CYP11B2 expression}

We next examined the effect of PPAR $\gamma$ overexpression on CYP11B2 transcriptional activity using previously described promoter/reporter constructs (Bassett et al. 2004). As shown in Fig. 2A, PPAR $\gamma$ overexpression attenuated the AII-mediated CYP11B2 transactivation both in the absence or presence of pioglitazone in a dose-dependent manner. We next examined the effects of PPAR $\gamma$ agonists/antagonist on CYP11B2 transcriptional activity. As shown in Fig. 2B, the AII-mediated $C Y P 11 B$ transactivation was also suppressed by rosiglitazone and GW1929 to a similar extent as pioglitazone. Moreover, the pioglitazone-mediated CYP11B transrepression was abrogated by a PPAR $\gamma$ antagonist, GW9662 (Fig. 2C).

We next investigated the effect of PPAR $\gamma$ AF-2 domain mutation on CYP11B2 transcriptional activity/ aldosterone secretion. In the presence of wild-type PPAR $\gamma$, pioglitazone suppressed both the AII-mediated CYP11B2 transactivation (Fig. 2D) and aldosterone secretion (Fig. 2E), while the pioglitazone-mediated suppression was canceled in the presence of PPAR $\gamma$ L466A/E469A mutant. Next, we examined the role of retinoid $\mathrm{X}$ receptor (RXR) on CYP11B2 transcriptional activity. As shown in Fig. 2F, an RXR agonist HX630 also suppressed the AII-induced CYP11B2 transcriptional activity and additively decreased the pioglitazone-mediated transrepression. These data suggest that pioglitazone suppressed CYP11B2 transcriptional activity and aldosterone secretion through PPAR $\gamma$.

\section{Pharmacological properties of pioglitazone on CYP11B2 transcriptional activity}

We next determined the pharmacological properties of pioglitazone on the AII-induced CYP11B2 transcriptional activity. Time-course analysis revealed that pioglitazone suppressed the AII-mediated CYP11B2 transactivation from $0.5 \mathrm{~h}$, with maximal suppression at $24 \mathrm{~h}$ (Fig. 3A). Pioglitazone suppressed the AIImediated CYP11B2 transactivation in a concentrationdependent manner (Fig. 3B).

We next examined whether pioglitazone suppresses potassium- and cAMP-mediated CYP11B2 expression. In addition to AII, potassium and the cAMP analogue dbcAMP increased both CYP11B2 transcriptional activity (Fig. 3C) and mRNA expression (Fig. 3D). Pioglitazone suppressed not only the AII- but also the potassium-mediated upregulation of CYP11B2 transcriptional activity (Fig. 3C) and mRNA expression (Fig. 3D), while it did not suppress the dbcAMPmediated stimulation. 


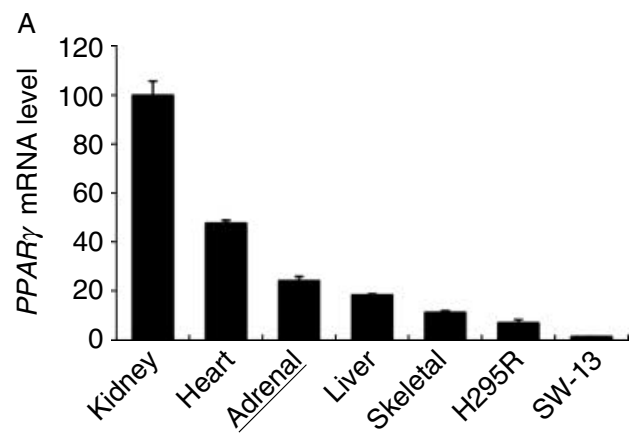

B

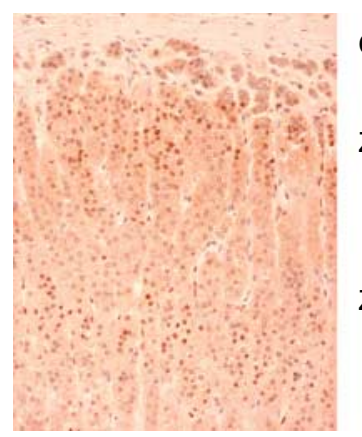

D

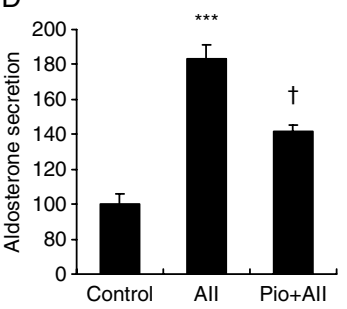

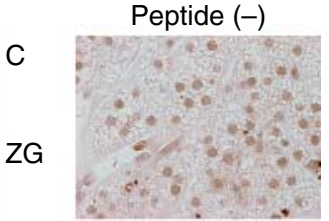

Peptide (+)

ZF

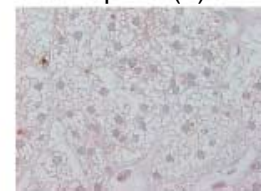

E

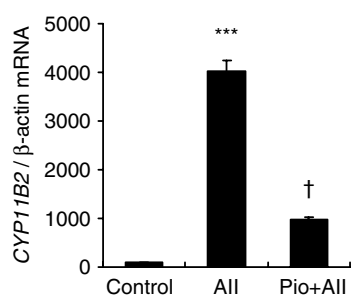

C

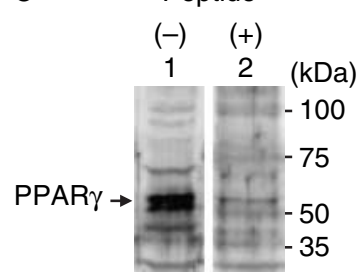

$\mathrm{F}$

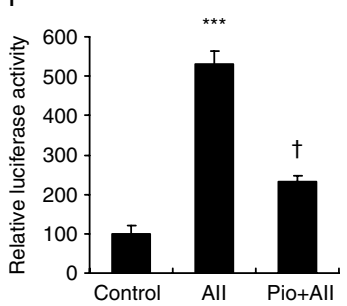

Figure 1 PPAR $\gamma$ expression and effect of pioglitazone on aldosterone production. (A) Expression of PPAR $\gamma$ mRNA in human organs, H295R, and SW-13 cells. Data represent mean \pm S.E.M. $(n=3)$, percent of kidney group, copies of PPAR $\gamma$ cDNA as determined by quantitative RT-PCR per $1 \mathrm{ng}$ total RNA. (B) Localization of PPAR $\gamma$ in human adrenal cortex determined by immunohistochemistry using anti-PPAR $\gamma$ antibody (left panel). Human adrenal cortex was stained by hematoxylin and anti-PPAR $\gamma$ antibody with (lower) or without (upper) pre-absorption by its antigen peptide (right panel).

(C) PPAR $\gamma$ protein expression in H295R cell nuclear protein determined by western immunoblot analyses. Immunoblot analyses were performed using anti-PPAR $\gamma$ antiserum in the absence (lane 1) or presence (lane 2) of blocking peptide. (D) Effect of pioglitazone on aldosterone secretion into the media from H295R cells. H295R cells were treated with pioglitazone (Pio; $10 \mu \mathrm{mol} / \mathrm{l}, 72 \mathrm{~h})$ and All $(100 \mathrm{nmol} / \mathrm{l}, 4 \mathrm{~h})$. Data represent mean \pm S.E.M. $(n=6)$, percent of control. (E) Effect of pioglitazone on CYP11B2 mRNA expression in $\mathrm{H} 295 \mathrm{R}$ cells. Cells were treated with pioglitazone (Pio; $10 \mu \mathrm{mol} / \mathrm{l}, 72 \mathrm{~h}$ ) and All $(100 \mathrm{nmol} / \mathrm{l}$, $6 \mathrm{~h})$. Data represent mean \pm S.E.M. $(n=4)$, percent of control, normalized by $\beta$-actin mRNA levels. (F) Effect of pioglitazone on CYP11B2 transcriptional activity. H295R cells transfected with $-1521 /+2$-luc and pCMV- $\beta$-gal were treated with pioglitazone (Pio; $10 \mu \mathrm{mol} / \mathrm{l}, 48 \mathrm{~h})$ and All (100 nmol/l, $4 \mathrm{~h})$. Data represent mean \pm S.E.M. $(n=4)$, percent of control. ${ }^{* \star} P<0.001$ versus control. ${ }^{\dagger} P<0.001$ versus All.

\section{Role of Ad1/CRE element on pioglitazone-mediated CYP11B2 transrepression}

To explore the mechanism(s) for the pioglitazonemediated CYP11B2 transrepression, we next examined the transcriptional activity of the CYP11B2 $5^{\prime}$-flanking region using its deletion mutants. Both the AII-induced (Fig. 4A) and potassium-induced (Fig. 4B) CYP11B2 transactivation and the pioglitazone-mediated suppression were observed in $-1521 /+2$-luc, $-747 /$ +2 -luc, and $-135 /+2$-luc. However, the AII- and potassium-mediated CYP11B2 transactivation and the 

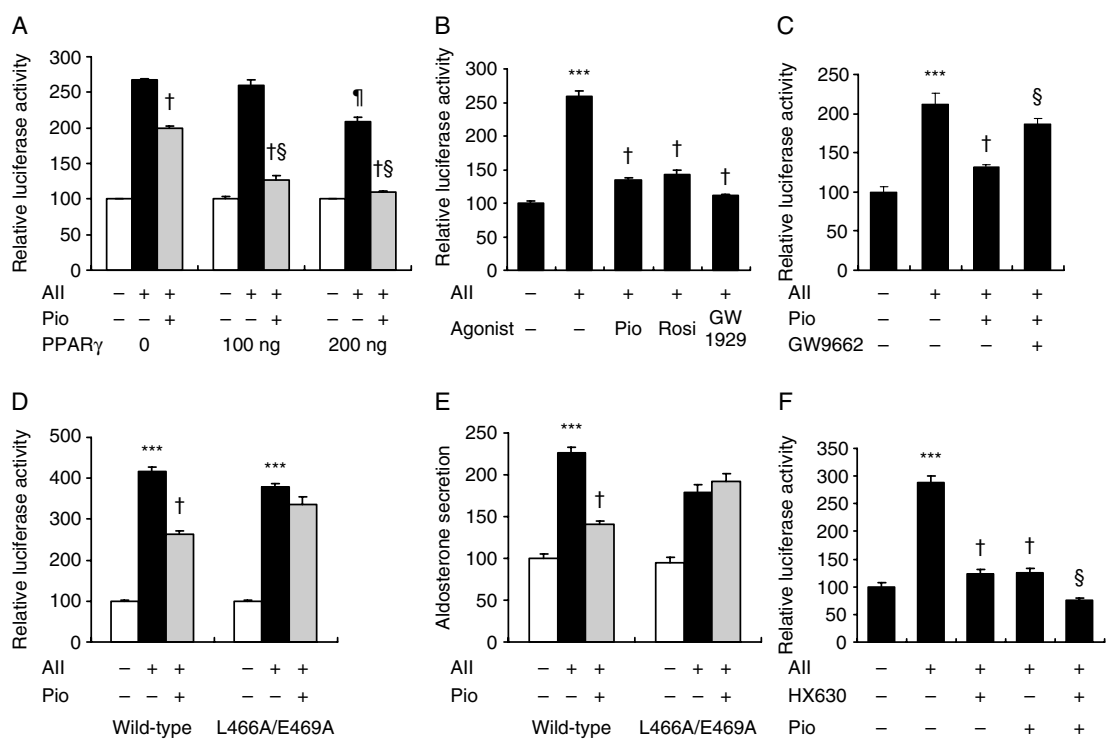

Figure 2 Role of PPAR $\gamma$ on $C Y P 11 B 2$ regulation. Effects of PPAR $\gamma$ overexpression $(A)$, PPAR $\gamma$ agonists (B), PPAR $\gamma$ antagonist (C), and PPAR $\gamma 1$ L466A/E469A mutant (D) on CYP11B2 transcriptional activity. H295R cells transiently transfected with $-1521 /+2$-luc, pCMV- $\beta$-gal, and PPAR $\gamma$ expression vectors (A, 0-200 ng, at indicated dose; B-D, $100 \mathrm{ng}$ ) were treated with reagents (A, $10 \mu \mathrm{mol} / \mathrm{l}$ pioglitazone (Pio), $72 \mathrm{~h}$; B-D, $3 \mu \mathrm{mol} / \mathrm{l}$ each Pio, rosiglitazone (Rosi), or GW1929, $20 \mu \mathrm{mol} / \mathrm{l} \mathrm{GW9662,} 48 \mathrm{~h}$ ) and All (100 nmol/l, $4 \mathrm{~h}$ ). Data represent mean \pm S.E.M. $(n=4)$, percent of control. (E) Effect of PPAR $\gamma 1 \mathrm{~L} 466 \mathrm{~A} / \mathrm{E} 469 \mathrm{~A}$ mutant on aldosterone secretion. H295R cells transiently transfected with $-1521 /+2$-luc, pCMV- $\beta$-gal, and PPAR $\gamma$ expression vectors $(100 \mathrm{ng})$ were treated with Pio $(3 \mu \mathrm{mol} / \mathrm{l}, 48 \mathrm{~h})$ and All (100 nmol/l, $4 \mathrm{~h})$. Data represent mean \pm s.E.M. $(n=4)$, percent control. (F) Effect of RXR on CYP11B2 transcriptional activity. H295R cells transiently transfected with -1521/+2-luc, pCMV- $\beta$-gal, and pCMX-PPAR $\gamma 1$ were treated with Pio $(10 \mu \mathrm{mol} / \mathrm{l}, 24 \mathrm{~h})$, HX630 (10 $\mu \mathrm{mol} / \mathrm{l}, 24 \mathrm{~h})$, and All $(100 \mathrm{nmol} / \mathrm{l}, 4 \mathrm{~h})$. Data represent mean \pm S.E.M. $(n=4)$, percent of control. Wild-type, pCMX-PPAR 1 ; L466A/E469A, pCMX-PPAR 1 L466A/E469A. (A) ${ }^{\dagger} P<0.001$ versus All. " $P<0.001$ versus All without PPAR $\gamma$ expression vector. ${ }^{\S} P<0.001$ versus All plus Pio without PPAR $\gamma$ expression vector. (B and D-F) ${ }^{\star \star \star} P<0.001$ versus control. ${ }^{\dagger} P<0.001$ versus All. (C) ${ }^{\star \star \star} P<0.001$ versus control. ${ }^{\dagger} P<0.001$ versus All. ${ }^{\S} P<0.001$ versus Pio plus All.

pioglitazone-mediated transrepression were not observed in $-65 /+2$-luc, which lacks both the Ad5 and Ad1/CRE elements. We thereafter examined the transcriptional activity of the Ad5 and Ad1/CRE elements in CYP11B2 $5^{\prime}$-flanking region using their mutants. As shown in Fig. 4C, mutation of the Ad5 element (-1521/+2-luc-Ad5-mut) partially abrogated both the AII- and potassium-induced CYP11B2 transcriptional activity comparing to the wild-type $-1521 /+2$-luc, but did not cancel the pioglitazonemediated CYP11B2 transrepression (AII, 40\% suppression in wild-type versus $34 \%$ suppression in Ad5-mut; potassium, $42 \%$ suppression in wild-type versus $46 \%$ suppression in Ad5-mut). On the other hand, mutation of the Ad1/CRE element (-1521/ +2-luc-Ad1/CRE-mut) strongly reduced both the AIIand potassium-induced CYP11B2 transcriptional activity, and abrogated the pioglitazone-mediated CYP11B2 transrepression (AII, 40\% suppression in wild-type versus $13 \%$ suppression in Ad1/CRE-mut; potassium, $42 \%$ suppression in wild-type versus $19 \%$ suppression in Ad1/CRE-mut). AII also increased the transcriptional activity of Ad1/CRE-SV-Luc, and pioglitazone suppressed the AII-mediated induction (Fig. 4D). AII or pioglitazone did not alter the transcriptional activity of pGL3-promoter (Fig. 4D). These data suggest that the Ad1/CRE element is probably responsible for the pioglitazone-mediated CYP11B2 transrepression. We next examined the effect of pioglitazone on the AII-induced expression of nerve growth factor-induced clone B (NGFIB) and NURR1, both of which are nuclear orphan receptors binding to the Ad5 element and positively regulate CYP11B2 transcriptional activity. Although AII increased both NGFIB and NURR1 mRNA expression, pioglitazone did not affect their expression (Supplementary Figure 1, see section on supplementary data given at the end of this article), indicating their lesser involvement in the transrepression. Consistent with the notion, pioglitazone had little effect on the NURR1-mediated CYP11B2 transactivation (Fig. 4E). 

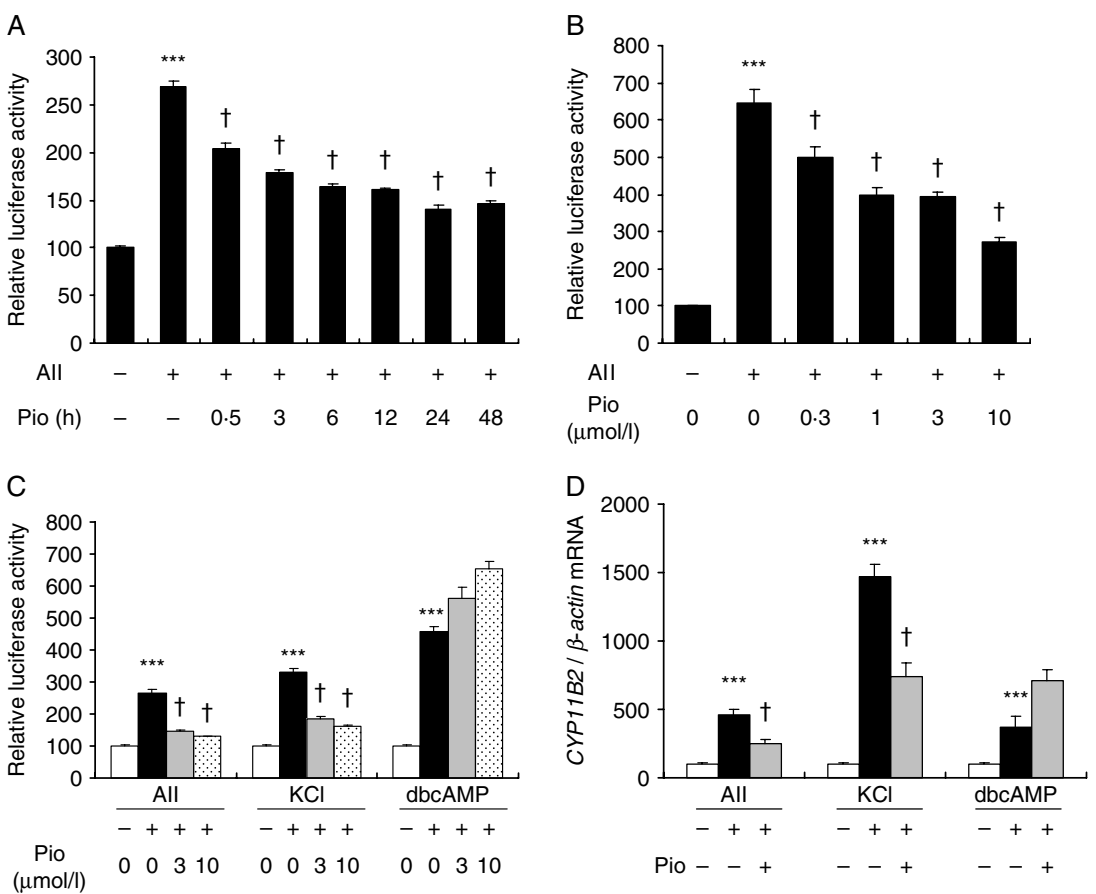

Figure 3 Pharmacological analyses of pioglitazone on H295R cells. (A and B) Time-course (A) and dose-response (B) effects of pioglitazone (Pio) on All-induced CYP11B2 transcriptional activity. (C) Effect of pioglitazone (Pio) on potassium- and dbcAMP-mediated CYP11B2 transactivation. H295R cells transiently transfected with $-1521 /+2$-luc, pCMV- $\beta$-gal, and pCMX-PPAR $\gamma 1$ were treated with Pio $(A, 3 \mu \mathrm{mol} / /$, the indicated duration before All addition; $B$ and $C$, the indicated concentration, $24 \mathrm{~h}$ ) and All (A and C, $100 \mathrm{nmol} / \mathrm{l}$; $\mathrm{B}, 200 \mathrm{nmol} / \mathrm{l}, 4 \mathrm{~h})$, and $\mathrm{KCl}\left(10.4 \mathrm{mmol} / \mathrm{l}, 16 \mathrm{mEq} / \mathrm{l}\right.$ of $\left.\mathrm{K}^{+}, 8 \mathrm{~h}\right)$ or $\mathrm{dbcAMP}(1 \mathrm{mmol} / \mathrm{l}, 4 \mathrm{~h})$ was thereafter added. Data represent mean \pm S.E.M. $(n=4)$, percent of control. (D) Effect of Pio on potassium- and dbcAMP-induced CYP11B2 mRNA expression. H295R cells transfected with $\mathrm{pCMX}-\mathrm{PPAR} \gamma 1$ were treated with Pio $(3 \mu \mathrm{mol} / \mathrm{l}, 48 \mathrm{~h})$, All $(100 \mathrm{nmol} / \mathrm{l}, 6 \mathrm{~h})$, $\mathrm{KCl}\left(10.4 \mathrm{mmol} / \mathrm{l}, 16 \mathrm{mEq} / \mathrm{l} \mathrm{of} \mathrm{K}^{+}, 12 \mathrm{~h}\right)$, or dbcAMP ( $\left.1 \mathrm{mmol} / \mathrm{l}, 6 \mathrm{~h}\right)$. mRNA expression was determined by quantitative RT-PCR. Data represent mean \pm S.E.M. $(n=4)$, percent of control, normalized by $\beta$-actin mRNA levels. ${ }^{\star \star \star} P<0.001$ versus control. ${ }^{\dagger} P<0.001$ versus All, $\mathrm{KCl}$, or dbcAMP.

\section{Role of pioglitazone on calcium signaling}

Since the Ad1/CRE element is essential for the AII- and potassium-mediated CYP11B2 transactivation via the $\mathrm{Ca}^{2+}$-CaM-CaMKI signaling pathway (Clyne et al. 1997, Pezzi et al. 1997, Condon et al. 2002), we therefore investigated the role of pioglitazone on this pathway. As shown in Fig. 5A and B, both AII and potassium increased intracellular calcium ion concentration in H295R cells. Although pioglitazone did not affect the AII-mediated intracellular $\mathrm{Ca}^{2+}$ increase, it enhanced the potassium-mediated one. We next examined the effect of pioglitazone on the $\mathrm{Ca}^{2+}$-mediated CYP11B2 transcriptional activity. As shown in Fig. 5C, ionomycin increased CYP11B2 transcriptional activity, while pioglitazone diminished the increase. We next examined the effects of pioglitazone on CaMs mRNA expression. As shown in Fig. 5D, the mRNA level of CaM3 was significantly higher than that of CaM1 and CaM2. Pioglitazone weakly increased the mRNA expression of both CaM1 and CaM2, while it did not affect that of CaM3. These data indicate that pioglitazone partially enhances, but not suppresses, the $\mathrm{Ca}^{2+}$-CaM signals.

\section{Role of CaMK on pioglitazone-mediated CYP11B2 transrepression}

Since CaMKI is known to stimulate CYP11B2 transcriptional activity through the Ad1/CRE element downstream of the $\mathrm{Ca}^{2+}-\mathrm{CaM}$ signals (Condon et al. 2002), we next examined the role of CaMKI on the pioglitazone-mediated CYP11B2 transrepression. In addition to CaMKI, CaMKIV is also reported to increase CYP11B2 transcriptional activity weakly (Condon et al. 2002). Therefore, we evaluated the expression level of CaMKI and IV. As shown in Fig. 6A, the mRNA expression of CaMKI in H295R cells was much higher than that of CaMKIV. Pioglitazone did not affect their mRNA expression level. Overexpression of a truncated 

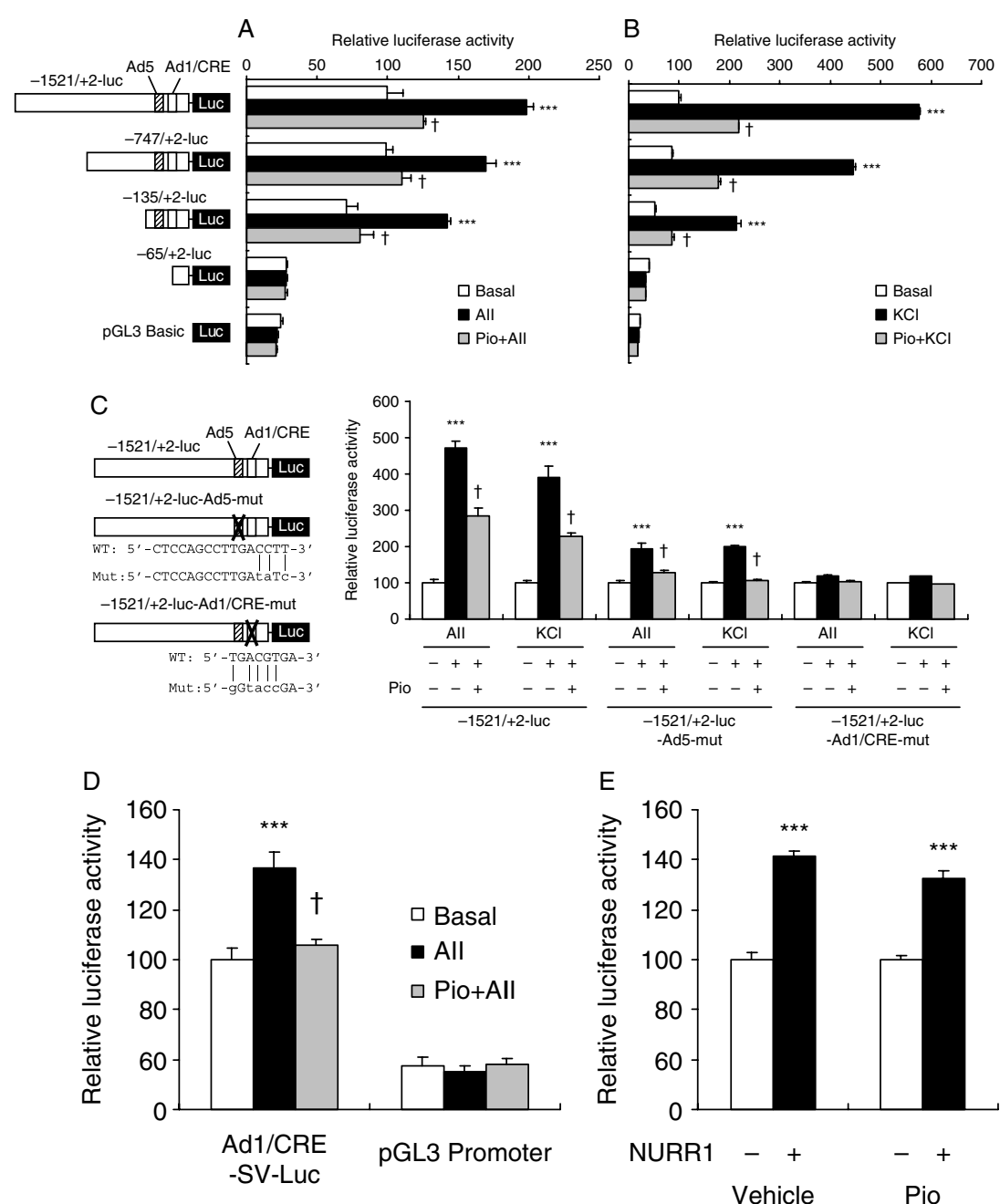

Figure 4 Effect of $C Y P 11 B 25^{\prime}$-flanking region mutant on pioglitazone-mediated CYP11B2 transrepression. (A-D) H295R cells transfected with luciferase-reporter vectors, $\mathrm{pCMV}$ - $\beta$-gal, and $\mathrm{pCMX-PPAR} \gamma 1$ were treated with pioglitazone (Pio; $3 \mu \mathrm{mol} / /$, $48 \mathrm{~h})$, All (100 nmol/l, $4 \mathrm{~h})$, or $\mathrm{KCl}\left(10.4 \mathrm{mmol} / \mathrm{l}, 16 \mathrm{mEq} / \mathrm{l}\right.$ of $\left.\mathrm{K}^{+}, 8 \mathrm{~h}\right)$. Data represent mean \pm S.E.M. $(n=4)$, percent of basal in $-1521 /+2$-luc group (A and $\mathrm{B})$, basal in each luciferase-reporter groups (C), or basal in Ad1/CRE-SV-Luc group (D). ${ }^{\star \star \star} P<0.001$ versus basal. ${ }^{\dagger} P<0.001$ versus All or $\mathrm{KCl}$. (E) Effect of Pio on NURR1-mediated CYP11B2 transcriptional activity. H295R cells were transfected with $-1521 /+2$-luc, pCMV- $\beta$-gal, pcDNA3 $(N U R R 1(-))$, or NURR1-pcDNA3 $(N U R R 1(+))$. Cells were treated with Pio $(3 \mu \mathrm{mol} / \mathrm{l}, 48 \mathrm{~h})$. Data represent mean \pm S.E.M. $(n=4)$, percent of NURR1 $(-) .{ }^{* \star *} P<0.001$ versus NURR1 $(-)$.

constitutively active form of CaMKI (CaMKI-295) increased CYP11B2 transcriptional activity (Fig. 6B), and pioglitazone completely abrogated the increase. As shown in Fig. 6C, the AII- or potassium-mediated $C Y P 11 B 2$ transactivation was not observed in the presence of a CaMK inhibitor KN-93. Additionally, the pioglitazone-mediated transrepression was also canceled in the presence of $\mathrm{KN}-93$. These data indicate that pioglitazone suppresses CYP11B2 transactivation probably via the suppression of signal transduction from CaMKI to CYP11B2 promoter.

\section{Discussion}

The present data demonstrate that PPAR $\gamma$ decreases CYP11B2 expression/aldosterone secretion through the suppression of CaMKI function that stimulates the Ad1/CRE element in CYP11B2 $5^{\prime}$-flanking region in the human adrenal H295R cells.

Expression of PPAR $\gamma$ in mouse (Kliewer et al. 1994) and human (Ferruzzi et al. 2005) adrenal gland has previously been demonstrated. Although $\operatorname{PPAR} \gamma$ agonists are reported to suppress androgen 

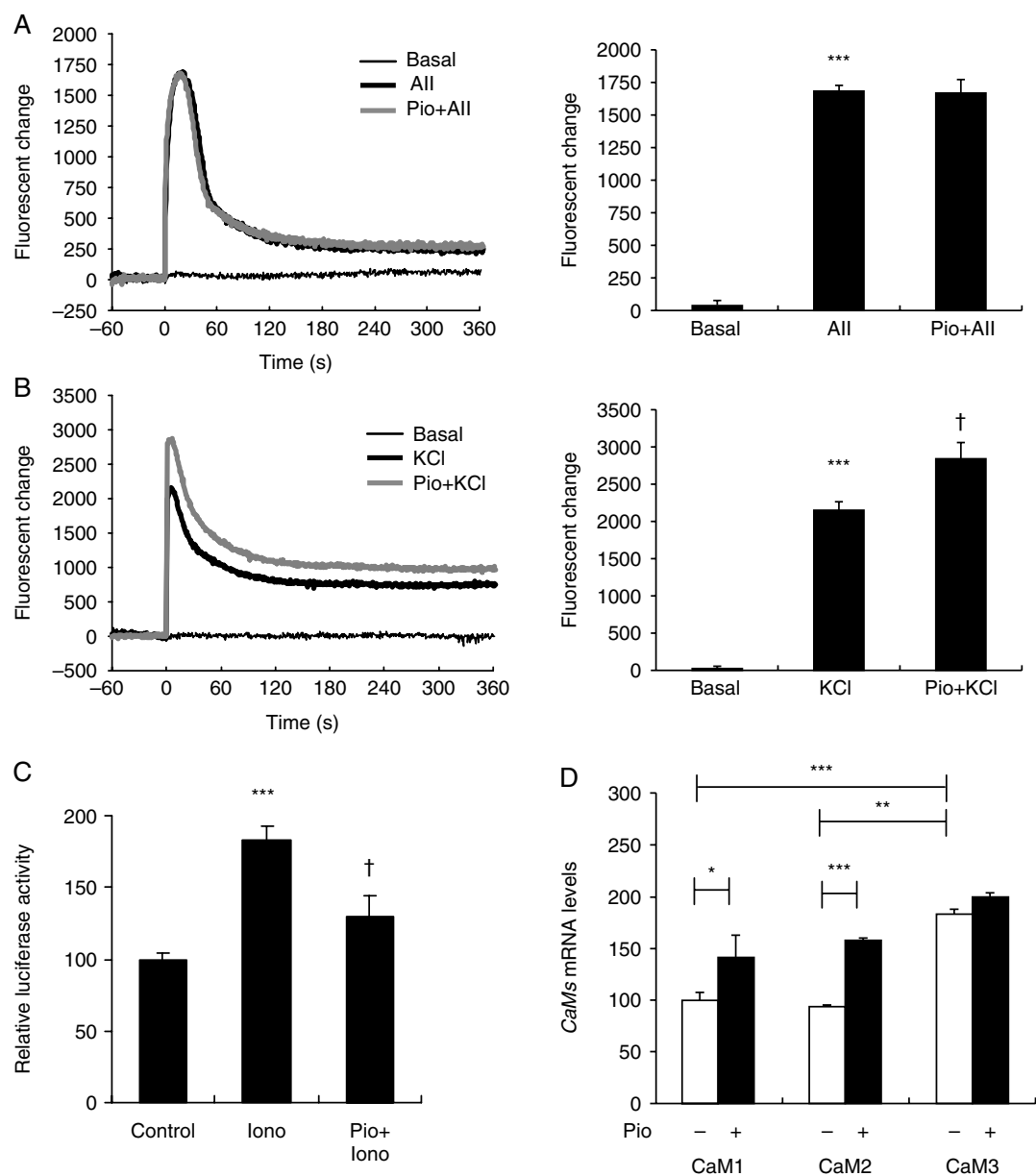

Figure 5 Role of pioglitazone on calcium regulation in H295R cells. (A and B) Effect of pioglitazone on intracellular calcium ion concentration in H295R cells determined by Fluo4-AM. H295R cells transfected with pCMX-PPAR $\gamma 1$ were treated with or without pioglitazone (Pio; $3 \mu \mathrm{mol} / \mathrm{l}, 24 \mathrm{~h}$ ). After loading with Fluo4-AM, cells were treated with All $(100 \mathrm{nmol} / \mathrm{l})$ or $\mathrm{KCl}(40 \mathrm{mmol} / \mathrm{l})$, and the fluorescence change was monitored. Data represent mean (the left panels, $n=5-6$ ) or mean \pm S.E.M. (the right panels, $n=5-6$ ), the fluorescence change from time 0 , arbitorary units. ${ }^{\star \star \star} P<0.001$ versus basal. ${ }^{\dagger} P<0.001$ versus $\mathrm{KCl}$. (C) Effect of Pio on ionomycin-induced CYP11B2 transcriptional activity. H295R cells were transfected with $-1521 /+2$-luc, pCMV- $\beta$-gal, and pCMX-PPAR $\gamma 1$. Cells were treated with Pio $(3 \mu \mathrm{mol} / \mathrm{l}, 48 \mathrm{~h})$ and ionomycin $(1 \mu \mathrm{mol} / \mathrm{l}, 4 \mathrm{~h})$. Data represent mean \pm S.E.M. $(n=4)$, percent of control. ${ }^{* \star *} P<0.001$ versus control. ${ }^{\dagger} P<0.001$ versus ionomycin. (D) Effect of Pio on CaMs mRNA expression. H295R cells transfected with $200 \mathrm{ng}$ pCMX-PPAR $\gamma 1$ were treated with (filled columns) or without (open columns) Pio $(3 \mu \mathrm{mol} / \mathrm{l}, 48 \mathrm{~h})$. Data represent mean \pm S.E.M. $(n=4)$, percent of CaM1 without Pio group, normalized by $\beta$-actin mRNA levels. ${ }^{\star \star \star} P<0.001$, ${ }^{\star \star} P<0.01,{ }^{\star} P<0.05$. Iono, ionomycin.

production and expression of $17 \alpha$-hydroxylase (CYP17) and 3ß-hydroxysteroid dehydrogenase type 2 (HSD3B2) in H295R cells (Kempna et al. 2007), as well as inhibit adrenal cancer cell line proliferation (Betz et al. 2005, Ferruzzi et al. 2005), these effects are shown to be independent of PPAR $\gamma$. Thus, the function of PPAR $\gamma$ in adrenal gland still remains uncertain. The PPAR $\gamma$ expression level in the normal human adrenal gland is reported to be lower than that in carcinoma as determined by immunohistochemistry
(Ferruzzi et al. 2005). In this study, we also demonstrated that the expression level of PPAR $\gamma$ in the human adrenal gland was higher than that in the liver and skeletal muscle (Fig. 1A). Additionally, immunohistochemistry of the normal human adrenal cortex revealed that PPAR $\gamma$ was predominantly localized in the zona glomerulosa (Fig. 1B). We therefore explored the roles of PPAR $\gamma$ in aldosterone production and CYP11B2 expression in the human adrenal cells. 

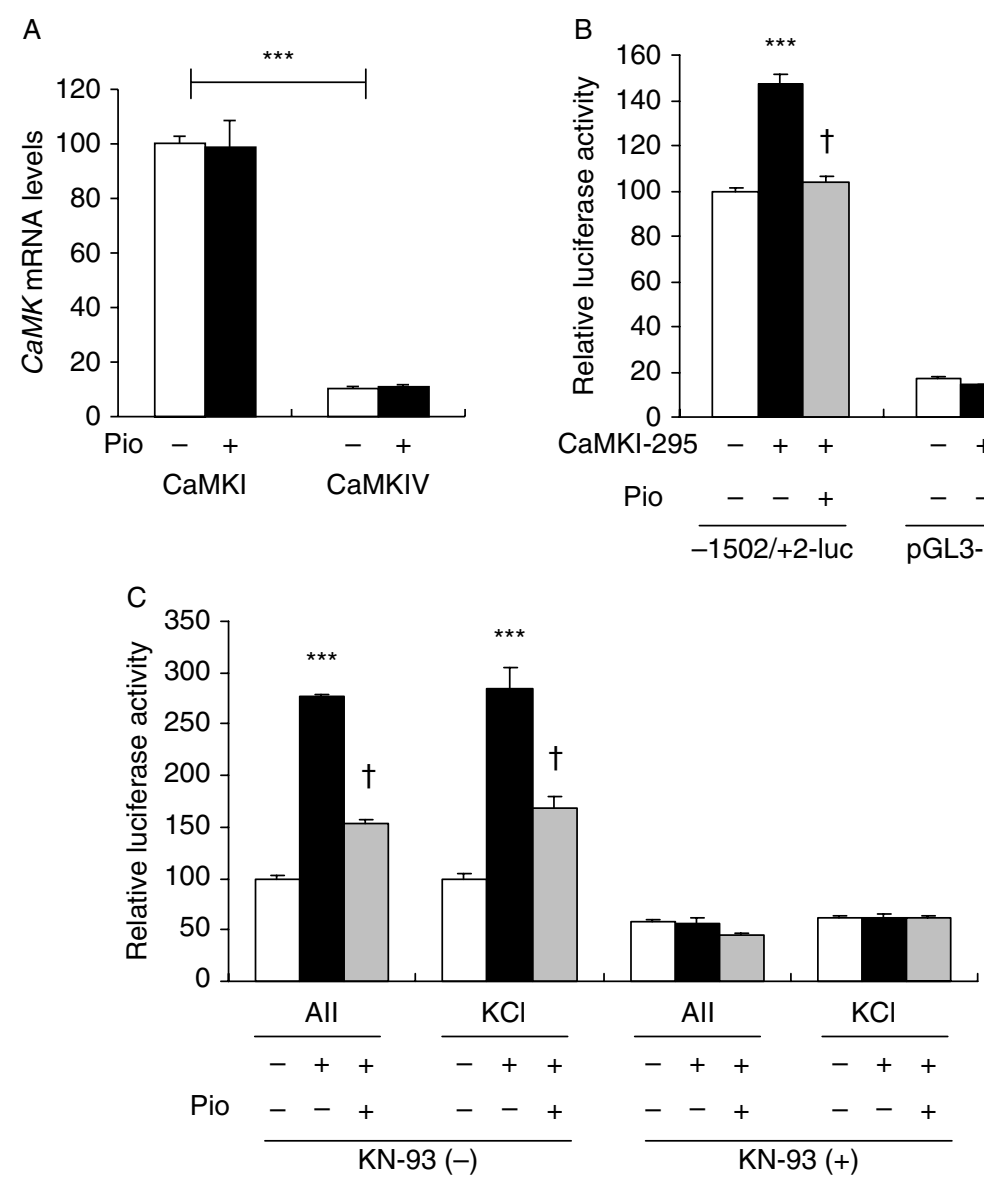

Figure 6 Effect of CaMK on pioglitazone-mediated CYP11B2 transrepression. (A) CaMKs mRNA expression. H295R cells transfected with $200 \mathrm{ng}$ pCMX-PPAR $\gamma 1$ were treated with (filled columns) or without (open columns) pioglitazone (Pio; $3 \mu \mathrm{mol} / \mathrm{l}, 48 \mathrm{~h}$ ). Data represent mean \pm S.E.M. $(n=4)$, percent of CaMKI without Pio group, normalized by $\beta$-actin mRNA levels. ${ }^{* \star} P<0 \cdot 001$. (B) Effect of Pio on CaMKI constitutively active formmediated CYP11B2 transcriptional activity. H295R cells were transfected with -1521 / +2-luc, pCMV- $\beta$-gal, pCMX-PPAR $\gamma$, pcDNA3 (CaMKI-295 (-)), or CaMKI-295-pcDNA3 $($ CaMKI-295 $(+))$. Cells were treated with Pio $(3 \mu \mathrm{mol} / \mathrm{l}, 48 \mathrm{~h})$. Data represent mean \pm S.E.M. $(n=4)$, percent of control. ${ }^{\star \star \star} P<0.001$ versus CaMKI-295 $(-) .{ }^{\dagger} P<0.001$ versus CaMKI-295 (+). (C) Effect of CaMK inhibitor KN-93 on Pio-mediated CYP11B2 transrepression. H295R cells were transfected with $-1521 /+2$-luc, pCMV- $\beta$-gal, and pCMX-PPAR $\gamma 1$. Cells were treated with Pio $(3 \mu \mathrm{mol} / \mathrm{l}, 48 \mathrm{~h})$, All $(100 \mathrm{nmol} / \mathrm{l}, 4 \mathrm{~h})$, or $\mathrm{KCl}$ $\left(10.4 \mathrm{mmol} / \mathrm{l}, 16 \mathrm{mEq} / \mathrm{l}\right.$ of $\left.\mathrm{K}^{+}, 8 \mathrm{~h}\right) . \mathrm{KN}-93$ was added to the media at $5 \mu \mathrm{mol} / \mathrm{l} 30 \mathrm{~min}$ prior to All or KCl addition. Data represent mean \pm S.E.M. $(n=4)$, percent of control. ${ }^{* \star *} P<0 \cdot 001$ versus control. ${ }^{\dagger} P<0.001$ versus All or $\mathrm{KCl}$.

Overexpression of PPAR $\gamma$ reduced the AII-induced $C Y P 11 B 2$ transcriptional activity as well as enhanced the suppressive effect of pioglitazone (Fig. 2A). Additionally, other PPAR $\gamma$ agonists rosiglitazone and GW1992 also suppressed the AII-induced CYP11B2 transcriptional activity (Fig. 2B). The effect of pioglitazone on CYP11B2 transcriptional activity was canceled by PPAR $\gamma$ antagonist GW9662 (Fig. 2C). These data therefore indicate that the pioglitazone-mediated suppression of aldosterone secretion and CYP11B2 expression are dependent on PPAR $\gamma$.
CaMKI is reported to be abundantly expressed in the human adrenal zona glomerulosa, and stimulate CYP11B2 transcriptional activity via the Ad1/CRE element in H295R cells more potently than CaMKIV (Condon et al. 2002). Additionally, we demonstrated in this study that the expression level of CaMKI in H295R cells was much higher than that of CaMKIV (Fig. 6A). Therefore, CaMKI is most likely a very important regulator for the Ad1/CRE element in the CYP11B2 promoter. The Ad1/CRE element in the CYP11B2 $5^{\prime}$-flanking region is bound by cAMP 
response-element-binding protein (CREB), activating transcriptional factor (ATF) 1, and ATF2 (Bassett et al. 2000). Interestingly, CREB and ATF1 are reported to be stimulated by CaMKI (Sun et al. 1996). Additionally, CREB is known to cooperate with coactivators including steroid receptor coactivator-1 (SRC-1) and p300/ CREB-binding protein (CBP) in the AII-induced gene expression (Sahar et al. 2007). Moreover, the pioglitazone-mediated CYP11B2 transrepression was canceled by PPAR $\gamma 1$ L466A/E469A mutant (Fig. 2D) whose function for the ligand-dependent recruitment of coactivators including SRC-1 and CBP is impaired (Gurnell et al. 2000). Therefore, these coactivators may be involved in the PPAR $\gamma$-mediated suppression of CYP11B2 expression.

The orphan nuclear receptors NGFIB, NURR1, and steroidogenic factor-1 (SF-1) bind to the Ad5 element in the CYP11B2 $5^{\prime}$-flanking region. NGFIB and NURR1 are known to be upregulated by AII or $\mathrm{KCl}$ and positively regulate $C Y P 11 B 2$ expression, while SF-1 negatively regulates CYP11B2 expression (Bassett $e t$ al. 2002). Since the AII/KCl-mediated upregulation of NURR1 is mediated via CaMK, the Ad5 element may possibly be influenced by CaMK (Bassett et al. 2004). However, the AII-induced NGFIB and NURR1 expressions were not suppressed by pioglitazone (Supplementary Figure 1), and the pioglitazonemediated transrepression was not canceled by mutation of the Ad5 element in CYP11B2 5'-flanking region (Fig. 4C). Therefore, the Ad5 element may not contribute to the pioglitazone-mediated CYP11B2 transrepression.

PPAR $\gamma 1$ L466A/E469A double mutant (L468A/ E471A in humans) is known to act similarly to PPAR $\gamma 1$ L466A single mutant (Park et al. 2003), but that in knockin mice develops hypertension (Freedman et al. 2005). Additionally, the PPAR $\gamma 1$ P467L natural mutant in the AF-2 domain (P465L in mice) induces insulin resistance and hypertension in humans (Barroso et al. 1999). Since mice expressing human PPAR $\gamma 1$ P467L mutant in VSMCs demonstrate vascular constriction and hypertension (Halabi et al. 2008), direct vascular effect may contribute to the progression of hypertension in this mutant. In the presence of PPAR $\gamma 1$ L466A/E469A mutant, impairment of ligandmediated suppression of aldosterone secretion was observed (Fig. 2E). Therefore, dysregulation of aldosterone production may be involved in the etiology of the PPAR $\gamma$ mutant-induced hypertension.

HX630 augmented the pioglitazone-mediated CYP11B2 transrepression (Fig. 2F). PPAR $\gamma$ heterodimerizes with RXR (Gearing et al. 1993), and binds to and activates PPAR-response elements (PPRE) in the promoter of target genes (IJpenberg et al. 1997). However, the Ad1/CRE element, the responsive element of the pioglitazone-mediated CYP11B2 transrepression, does not contain any consensus PPRE referred to as direct repeat 1 element. Therefore, PPAR $\gamma$ may suppress CYP11B2 transcriptional activity as a heterodimer with RXR without direct biding to the Ad1/CRE element.

In this study, we used pioglitazone at concentrations of 3 or $10 \mu \mathrm{mol} / \mathrm{l}$. The experimental concentrations of TZDs are above $10 \mu \mathrm{mol} / \mathrm{l}$, but TZDs exert some effects, which are PPAR $\gamma$-independent in NIC-h295 cells at high concentrations (10 $\mu \mathrm{mol} / \mathrm{l}$; Betz et al. 2005). Plasma concentration of pioglitazone reaches approximately to $4 \mu \mathrm{mol} / \mathrm{l}$ by $30 \mathrm{mg}$ oral administration in healthy male humans (Takeda Pharmaceuticals, Osaka, Japan). We tested the effects of pioglitazone at $10 \mu \mathrm{mol} / \mathrm{l}$ on aldosterone secretion and CYP11B2 gene regulation that may include both PPAR $\gamma$-dependent and -independent effects (Figs 1 and 2A). Therefore, we used pioglitazone at $3 \mu \mathrm{mol} / \mathrm{l}$, which is similar to the human plasma concentration after oral administration, to exclude PPAR $\gamma$-independent effects of pioglitazone in most experiments. However, in Fig. 2F, we treated the cells with pioglitazone at $10 \mu \mathrm{mol} / 1$ for $24 \mathrm{~h}$ to compare with HX630 at the same pharmacological conditions.

Pioglitazone potentially increased dbcAMP-induced CYP11B2 transcriptional activity and mRNA expression (Fig. 3C and D). Pioglitazone may increase the dbcAMP-mediated activation of CREB/ATF1, and further studies are needed to be examined.

In conclusion, our observation that PPAR $\gamma$ suppresses CYP11B2 expression/aldosterone secretion through CaMK may account for the suppressive effects of PPAR $\gamma$ on vascular events associated with atherosclerosis and hypertension.

\section{Supplementary data}

This is linked to the online version of the paper at http://dx.doi.org/ 10.1677/JME-10-0088.

\section{Declaration of interest}

The authors declare that there is no conflict of interest that could be perceived as prejudicing the impartiality of the research reported.

\section{Funding}

This work was supported by grants-in-aid from the Ministry of Education, Culture, Sports, Science, and Technology of Japan (to AU, no. 17790545; to AS, no. 16590898; and to SI, no. 17390245); grants-in-aid from the Ministry of Health, Labor, and Welfare of Japan (to AS); and research grants from Smoking Research Foundation (to AS). 


\section{Acknowledgements}

We thank Dr T Suzuki (Tohoku University) for providing H295R cells and Dr H Kagechika (Tokyo Medical and Dental University) for providing HX630.

\section{References}

Barroso I, Gurnell M, Crowley VE, Agostini M, Schwabe JW, Soos MA, Maslen GL, Williams TD, Lewis H, Schafer AJ et al. 1999 Dominant negative mutations in human PPAR $\gamma$ associated with severe insulin resistance, diabetes mellitus and hypertension. Nature 402 880-883. (doi:10.1038/47254)

Bassett MH, Zhang Y, White PC \& Rainey WE 2000 Regulation of human CYP11B2 and CYP11B1: comparing the role of the common CRE/Ad1 element. Endocrine Research 26 941-951. (doi:10.3109/ 07435800009048620 )

Bassett MH, Zhang Y, Clyne C, White PC \& Rainey WE 2002 Differential regulation of aldosterone synthase and 11ß-hydroxylase transcription by steroidogenic factor-1. Journal of Molecular Endocrinology 28 125-135. (doi:10.1677/jme.0.0280125)

Bassett MH, Suzuki T, Sasano H, White PC \& Rainey WE 2004 The orphan nuclear receptors NURR1 and NGFIB regulate adrenal aldosterone production. Molecular Endocrinology 18 279-290. (doi:10.1210/me.2003-0005)

Betz MJ, Shapiro I, Fassnacht M, Hahner S, Reincke M \& Beuschlein F 2005 Peroxisome proliferator-activated receptor- $\gamma$ agonists suppress adrenocortical tumor cell proliferation and induce differentiation. Journal of Clinical Endocrinology and Metabolism 90 3886-3896. (doi:10.1210/jc.2004-1267)

Clyne CD, Zhang Y, Slutsker L, Mathis JM, White PC \& Rainey WE 1997 Angiotensin II and potassium regulate human CYP11B2 transcription through common cis-elements. Molecular Endocrinology 11 638-649. (doi:10.1210/me.11.5.638)

Condon JC, Pezzi V, Drummond BM, Yin S \& Rainey WE 2002 Calmodulin-dependent kinase I regulates adrenal cell expression of aldosterone synthase. Endocrinology 143 3651-3657. (doi:10.1210/ en.2001-211359)

Diep QN, El Mabrouk M, Cohn JS, Endemann D, Amiri F, Virdis A, Neves MF \& Schiffrin EL 2002 Structure, endothelial function, cell growth, and inflammation in blood vessels of angiotensin II-infused rats: role of peroxisome proliferator-activated receptor- $\gamma$. Circulation 105 2296-2302. (doi:10.1161/01.CIR.0000016049. 86468.23)

Dormandy JA, Charbonnel B, Eckland DJ, Erdmann E, MassiBenedetti M, Moules IK, Skene AM, Tan MH, Lefebvre PJ, Murray GD et al. 2005 Secondary prevention of macrovascular events in patients with type 2 diabetes in the PROactive Study (PROspective pioglitAzone Clinical Trial In macroVascular Events): a randomised controlled trial. Lancet 366 1279-1289. (doi:10.1016/S0140-6736 (05) 67528-9)

Ferruzzi P, Kliewer P, Ceni E, Tarocchi M, Grappone C, Milani S, Galli A, Fiorelli G, Serio M \& Mannelli M 2005 Thiazolidinediones inhibit growth and invasiveness of the human adrenocortical cancer cell line H295R. Journal of Clinical Endocrinology and Metabolism 90 1332-1339. (doi:10.1210/jc.2004-0978)

Freedman BD, Lee EJ, Park Y \& Jameson JL 2005 A dominant negative peroxisome proliferator-activated receptor- $\gamma$ knock-in mouse exhibits features of the metabolic syndrome. Journal of Biological Chemistry 280 17118-17125. (doi:10.1074/jbc.M407539200)

Gearing KL, Gottlicher M, Teboul M, Widmark E \& Gustafsson JA 1993 Interaction of the peroxisome-proliferator-activated receptor and retinoid X receptor. PNAS 90 1440-1444. (doi:10.1073/pnas.90.4. 1440)

Guan Y, Hao C, Cha DR, Rao R, Lu W, Kohan DE, Magnuson MA, Redha R, Zhang Y \& Breyer MD 2005 Thiazolidinediones expand body fluid volume through PPAR $\gamma$ stimulation of ENaC-mediated renal salt absorption. Nature Medicine 11 861-866. (doi:10.1038/ nm1278)

Gurnell M, Wentworth JM, Agostini M, Adams M, Collingwood TN, Provenzano C, Browne PO, Rajanayagam O, Burris TP, Schwabe JW et al. $2000 \mathrm{~A}$ dominant-negative peroxisome proliferator-activated receptor $\gamma(\operatorname{PPAR} \gamma)$ mutant is a constitutive repressor and inhibits PPAR $\gamma$-mediated adipogenesis. Journal of Biological Chemistry $\mathbf{2 7 5}$ 5754-5759. (doi:10.1074/jbc.275.8.5754)

Halabi CM, Beyer AM, de Lange WJ, Keen HL, Baumbach GL, Faraci FM \& Sigmund CD 2008 Interference with PPAR $\gamma$ function in smooth muscle causes vascular dysfunction and hypertension. Cell Metabolism 7 215-226. (doi:10.1016/j.cmet.2007.12.008)

Harte A, McTernan P, Chetty R, Coppack S, Katz J, Smith S \& Kumar S 2005 Insulin-mediated upregulation of the renin angiotensin system in human subcutaneous adipocytes is reduced by rosiglitazone. Circulation 111 1954-1961. (doi:10.1161/01.CIR.0000161954. $17870.5 \mathrm{D})$

Heikkinen S, Auwerx J \& Argmann CA 2007 PPAR $\gamma$ in human and mouse physiology. Biochimica et Biophysica Acta 1771 999-1013. (doi:10.1016/j.bbalip.2007.03.006)

IJpenberg A, Jeannin E, Wahli W \& Desvergne B 1997 Polarity and specific sequence requirements of peroxisome proliferator-activated receptor (PPAR)/retinoid X receptor heterodimer binding to DNA. A functional analysis of the malic enzyme gene PPAR response element. Journal of Biological Chemistry 272 20108-20117. (doi:10.1074/jbc.272.32.20108)

Ikeda Y, Sugawara A, Taniyama Y, Uruno A, Igarashi K, Arima S, Ito S \& Takeuchi K 2000 Suppression of rat thromboxane synthase gene transcription by peroxisome proliferator-activated receptor $\gamma$ in macrophages via an interaction with NRF2. Journal of Biological Chemistry 275 33142-33150. (doi:10.1074/jbc.M002319200)

Jiang C, Ting AT \& Seed B 1998 PPAR- $\gamma$ agonists inhibit production of monocyte inflammatory cytokines. Nature 391 82-86. (doi:10.1038/ 35154)

Kempna P, Hofer G, Mullis PE \& Fluck CE 2007 Pioglitazone inhibits androgen production in NCI-H295R cells by regulating gene expression of CYP17 and HSD3B2. Molecular Pharmacology 71 787-798. (doi:10.1124/mol.106.028902)

Kliewer SA, Forman BM, Blumberg B, Ong ES, Borgmeyer U, Mangelsdorf DJ, Umesono K \& Evans RM 1994 Differential expression and activation of a family of murine peroxisome proliferator-activated receptors. PNAS 91 7355-7359. (doi:10.1073/ pnas.91.15.7355)

Park Y, Freedman BD, Lee EJ, Park S \& Jameson JL 2003 A dominant negative PPAR $\gamma$ mutant shows altered cofactor recruitment and inhibits adipogenesis in 3T3-L1 cells. Diabetologia 46 365-377. (doi:10.1007/s00125-003-1177-6)

Pezzi V, Clyne CD, Ando S, Mathis JM \& Rainey WE $1997 \mathrm{Ca}^{2+}$. regulated expression of aldosterone synthase is mediated by calmodulin and calmodulin-dependent protein kinases. Endocrinology 138 835-838. (doi:10.1210/en.138.2.835)

Rainey WE, Saner K \& Schimmer BP 2004 Adrenocortical cell lines. Molecular and Cellular Endocrinology 228 23-38. (doi:10.1016/j.mce. 2003.12.020)

Ricote M, Li AC, Willson TM, Kelly CJ \& Glass CK 1998 The peroxisome proliferator-activated receptor- $\gamma$ is a negative regulator of macrophage activation. Nature 391 79-82. (doi:10. 1038/34178)

Rocha R, Stier CT Jr, Kifor I, Ochoa-Maya MR, Rennke HG, Williams GH \& Adler GK 2000 Aldosterone: a mediator of myocardial necrosis and renal arteriopathy. Endocrinology 141 3871-3878. (doi:10.1210/en.141.10.3871)

Rocha R, Martin-Berger CL, Yang P, Scherrer R, Delyani J \& McMahon E 2002 Selective aldosterone blockade prevents angiotensin II/saltinduced vascular inflammation in the rat heart. Endocrinology 143 4828-4836. (doi:10.1210/en.2002-220120) 
Ryan MJ, Didion SP, Mathur S, Faraci FM \& Sigmund CD 2004 $\operatorname{PPAR}(\gamma)$ agonist rosiglitazone improves vascular function and lowers blood pressure in hypertensive transgenic mice. Hypertension 43 661-666. (doi:10.1161/01.HYP.0000116303. 71408.c2)

Sahar S, Reddy MA, Wong C, Meng L, Wang M \& Natarajan R 2007 Cooperation of SRC-1 and p300 with NF- $\mathrm{KB}$ and CREB in angiotensin II-induced IL-6 expression in vascular smooth muscle cells. Arteriosclerosis, Thrombosis, and Vascular Biology 27 1528-1534. (doi:10.1161/ATVBAHA.107.145862)

Sato K, Sugawara A, Kudo M, Uruno A, Ito S \& Takeuchi K 2004 Expression of peroxisome proliferator-activated receptor isoform proteins in the rat kidney. Hypertension Research 27 417-425. (doi:10. 1291/hypres.27.417)

Sugawara A, Takeuchi K, Uruno A, Ikeda Y, Arima S, Kudo M, Sato K, Taniyama Y \& Ito S 2001 Transcriptional suppression of type 1 angiotensin II receptor gene expression by peroxisome proliferator-activated receptor- $\gamma$ in vascular smooth muscle cells. Endocrinology 142 3125-3134. (doi:10.1210/en.142.7. 3125)

Sugawara A, Uruno A, Kudo M, Ikeda Y, Sato K, Taniyama Y, Ito S \& Takeuchi K 2002 Transcription suppression of thromboxane receptor gene by peroxisome proliferator-activated receptor- $\gamma$ via an interaction with $\mathrm{Sp} 1$ in vascular smooth muscle cells. Journal of Biological Chemistry 277 9676-9683. (doi:10.1074/jbc. M104560200)

Sun P, Lou L \& Maurer RA 1996 Regulation of activating transcription factor- 1 and the cAMP response element-binding protein by $\mathrm{Ca}^{2+}$ / calmodulin-dependent protein kinases type I, II, and IV. Journal of Biological Chemistry 271 3066-3073. (doi:10.1074/jbc.271. 6.3066)
Todorov VT, Desch M, Schmitt-Nilson N, Todorova A \& Kurtz A 2007 Peroxisome proliferator-activated receptor- $\gamma$ is involved in the control of renin gene expression. Hypertension 50 939-944. (doi:10. 1161/HYPERTENSIONAHA.107.092817)

Uruno A, Sugawara A, Kanatsuka H, Arima S, Taniyama Y, Kudo M, Takeuchi K \& Ito S 2004 Hepatocyte growth factor stimulates nitric oxide production through endothelial nitric oxide synthase activation by the phosphoinositide 3-kinase/Akt pathway and possibly by mitogen-activated protein kinase kinase in vascular endothelial cells. Hypertension Research 27 887-895. (doi:10.1291/ hypres.27.887)

Uruno A, Sugawara A, Kanatsuka H, Kagechika H, Saito A, Sato K, Kudo M, Takeuchi K \& Ito S 2005 Upregulation of nitric oxide production in vascular endothelial cells by all-trans retinoic acid through the phosphoinositide 3-kinase/Akt pathway. Circulation 112 727-736. (doi:10.1161/CIRCULATIONAHA.104.500959)

Uruno A, Sugawara A, Kudo M, Satoh F, Saito A \& Ito S 2008 Stimulatory effects of low-dose 3-hydroxy-3-methylglutaryl coenzyme a reductase inhibitor fluvastatin on hepatocyte growth factorinduced angiogenesis: involvement of p38 mitogen-activated protein kinase. Hypertension Research 31 2085-2096. (doi:10.1291/ hypres.31.2085)

Walker AB, Chattington PD, Buckingham RE \& Williams G 1999 The thiazolidinedione rosiglitazone (BRL-49653) lowers blood pressure and protects against impairment of endothelial function in Zucker fatty rats. Diabetes 48 1448-1453. (doi:10.2337/diabetes. 48.7.1448)

\section{Received in final form 31 October 2010 \\ Accepted 24 November 2010}

Made available online as an Accepted Preprint 24 November 2010 